\section{Funding crisis could spell the end for millimetre telescope}

Rex Dalton, San Diego

The National Science Foundation (NSF) has announced that it will no longer fund operation of the 12-metre telescope at Kitt Peak in Arizona - raising the likelihood that the historic instrument will finally shut down.

The funding agency has told the University of Arizona and the University of Massachusetts at Amherst that their proposal to operate the telescope for $\$ 2.4$ million for three years was being rejected because of a tightening NSF budget.

Owned by the NSF since it opened in 1967 , the telescope is the only facility in the United States for millimetrewavelength radio astronomy that is fully open to outside researchers.

The University of Arizona has been operating the telescope since last July, when the NSF said that it would no longer bear the operation costs on a permanent basis. The Tucson-based Research Corporation stepped in with philanthropic funds for interim operations while a new NSF grant was sought.

Reviewers of the proposal to the NSF gave the project high marks, Arizona officials say, but NSF administrators said money was not available given the Bush administration's budget proposal.

"We are simply dumbfounded," says Peter Strittmatter, director of Arizona's Steward Observatory and leader of the grant proposal to the NSF. "The importance of the telescope to the US astronomy community was clearly recognized by all the reviewers."

The University of Arizona will now begin a search for alternative funding to try to keep the telescope open for the 100-plus astronomers that use it. "We will keep our shoestring operation going" while trying to find groups to guarantee purchase of time on the telescope, says Strittmatter.

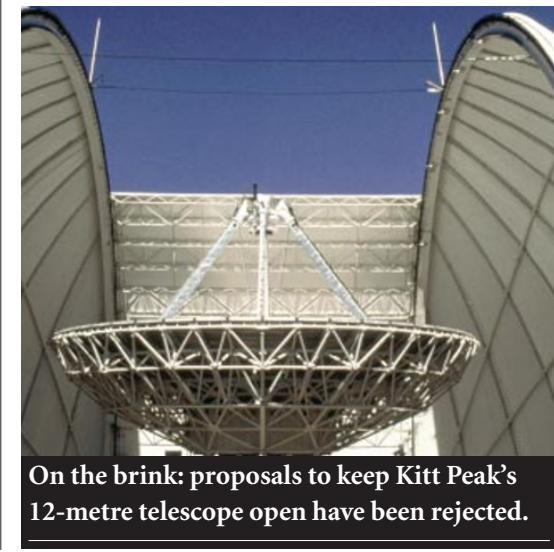

\title{
Professors facing power cuts in German university reforms
}

\section{Marco Jäger and Quirin Schiermeier, Munich}

German universities are set for a radical reform that will curb the pervasive powers of senior professors and provide more freedom and financial incentive for junior ones.

Under legislation presented last week by science minister Edelgard Bulmahn, professors will be paid on the basis of performance rather than seniority. But the rules, which should be in force by next year, will only apply to new professors and to existing ones who choose to take them up.

The reforms are opposed by academic organizations in Germany, despite the fact that many younger academics support the change.

Under the proposals, the archaic qualification required for professorship in Germany - known as Habilitation — would be phased out by 2010. Junior professorships, similar to US assistant professorships, would gradually replace Habilitation.

In addition, professors' basic monthly salaries, which currently range from DM7,000 (US\$3,300) to DM18,000 depending on age and position, would be reduced by a third, and bonuses would be paid to those who meet or exceed performance targets. The current DM18,000 salary limit would be lifted - a move that is considered necessary to attract top international researchers to German universities.

Bulmahn last week sent the reform proposals to the 16 Länder (state) governments, which are responsible for education. They are expected to enact the changes as they were involved in the commission that drew up the reforms.

But Germany's academic establishment has already criticized the changes, which have been under discussion for two years. Last March, for example, almost 4,000 faculty members, including emeritus professors, signed a letter of protest published as an advertisement in the newspaper Frankfurter Allgemeine Zeitung.

The advertisement was paid for by the Deutsche Hochschulverband, the largest association of German university professors. Hartmut Schiedermair, president of the association, strongly opposes Bulmahn's plans.

Some younger scientists disagree with the association's position. Hartmut Engelmann, for example, a 42-year-old immunologist at the University of Munich, who underwent Habilitation two years ago, says he will be glad to see the back of the process.

"There is no transparency at all, only personal dependence," he says. "Everything is fine if your institute head is well-disposed

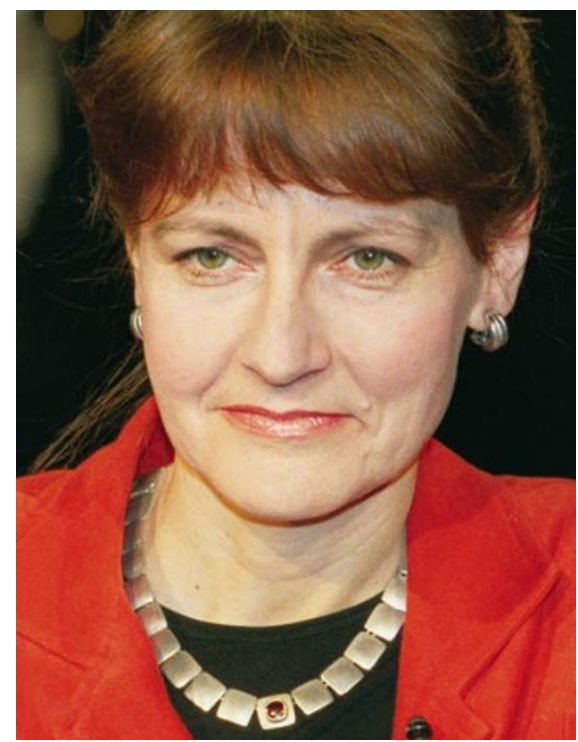

In with the new: science minister Edelgard Bulmahn aims to encourage younger academics.

towards you. If not, it can eat you up."

Engelmann also welcomes the idea that professors should be paid on the basis of the quality of their teaching and research. But he admits that it will be difficult to carry out fair evaluations.

Bulmahn has not yet specified details of how these evaluations will be done. According to a spokeswoman for the education department, options include assessing the number of scientific publications and using students" evaluations of lectures. "Only practical experience will teach us where to position the lever," she says.

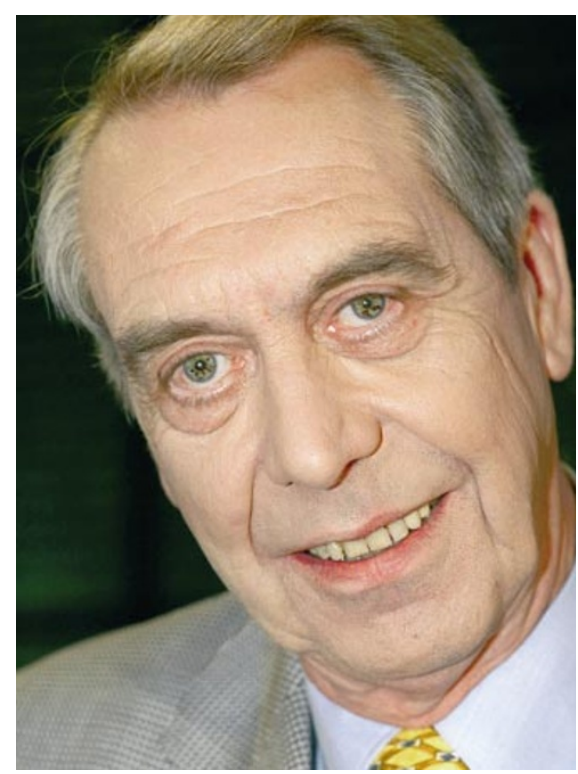

Standing firm: Hartmut Schiedermair is leading professorial opposition to the reforms. 